\title{
Reproduction Characteristics of Rice Field Eel (Monopterus albus Zuieuw) on Several Functionally Changed Lands in Banyumas Regency
}

Priyo Susatyo, Nuning Setyaningrum, Elly Tuti Winarni, Titi Chasanah, Atang

Department of Biology, Jendral Soedirman University, Purwokerto, Indonesia

\begin{abstract}
Functional change of agricultural lands into non-agricultural lands will obviously have an impact on the diminished or loss of habitat of the rice field eels (Monopterus albus Zuieuw). The aim of this research was to understand the difference between (1) reproduction parameters (fecundity, gonadal maturity level (GML), and gonadal maturity index (GMI); (2) histological features of female and male gonadal development (oogenesis and spermatogenesis); (3) range of body length in each sexual phase; and (4) range of body length in each GML stage of captured eel from 4 sub-districts of Banyumas regency, Central Java (Ajibarang, Sumpyuh, Banyumas, and Sumbang). The total number of captured subjects were 631 eels; which consisted of 155; 227; 157; and 92 eels from Ajibarang, Sumpyuh, Banyumas, and Sumbang, respectively. We observed oogenesis in the stages of GML-1 (chromatin nucleolar stages and perinucleolar stage); GML-II (cortical alveolar formation stage or globular yolk stage), GML-3 (late globular yolk stage), GML-IV (mature or ripe stage), and follicle atretic stage. Also, we observed male gonadogenesis and spermatogenesis in the intersex. The range of GMI of captured eels was between 0.023 and 0.686. Eel in GML-I, GML-2, GML-3, and GML-IV had GMI within the range of 0.023-0.096; 0.096-0.425; 0.427-0.686; and >0.686, respectively. Eels achieved stage of GML-IV in body length range of 22.6-34.5 cm in Sumpyuh, $22.6-38.5 \mathrm{~cm}$ in Ajibarang, and 26.6-34.5 cm in Banyumas. There was no eel with the status of GML-IV in Sumbang, which had the most residential or functionally changed lands in its area. Based on these findings, can be concluded that the condition of rice fields or habitat of eel in functionally changed lands may affect eel's growth and gonad maturation.
\end{abstract}

Keywords: Rice field eel (Monopterus albus Zuieuw), Gonad Maturity Level (GML), Gonad Maturity Index (GSI), Oogenesis

\section{INTRODUCTION}

Functional change of agricultural lands (rice fields or green farming area) into non-agricultural lands (residential or industrial area) are currently inevitable [1]. This condition may threaten the habitat of living things within the area and cause environmental imbalance. One of the living creatures, which are currently threatened to lose their habitat is rice field eel (Monopterus albus Zuieuw) [2].

Rice field eel is the original fish from Indonesia (Figure 1). This fish can exploit oxygen from the atmosphere. Therefore, it can survive in limited water condition. It also has a tolerance of temperature and salinity [3]. Also, eel can pass through wet soil for migration [4]. We can find Eels in other Asian countries, including India, China, Japan, and Malaysia [5].

*Corresponding author:

Priyo Susatyo

Department of Biology, Jendral Soedirman University

Jalan HR. Boenyamin, Purwokerto, Indonesia 53122

E-mail: priyo.susatyo@unsoed.ac.id

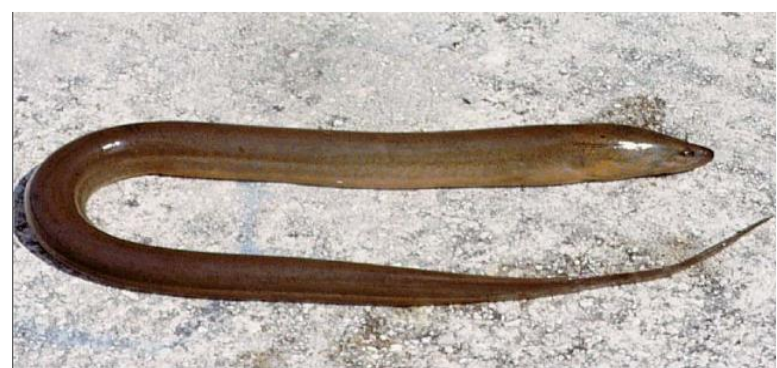

Figure 1. Rice field eel (Monopterus albus Zuieuw)

In China, eel is the most important and economically valuable fish [6]. Yin and Liu [6] reported that eel production in China in 2004 was 137,486 tons. Eel protein is rich in several essential amino acids, such as lysine and methionine. Also, it contains phosphorus, crude fiber, and calcium. Eel can give benefit either as

\section{How to cite:}

Susatyo P, Setyaningrum N, Winarni ET et al. (2018) Reproduction Characteristics of Rice Field Eel (Monopterus albus Zuieuw) on Several Functionally Changed Lands in Banyumas Regency. J. Trop. Life. Science 8 (2): 177 - 186. 


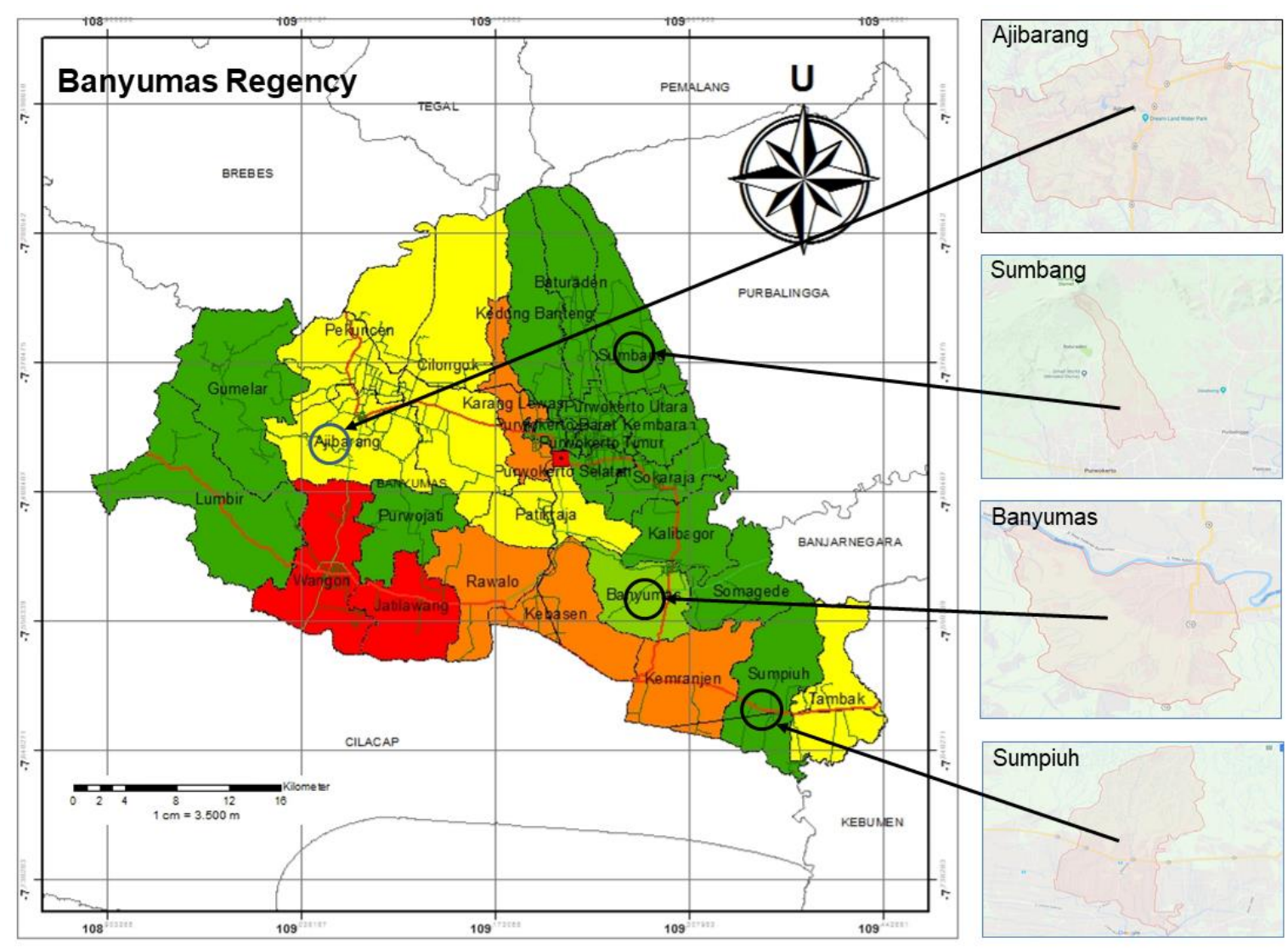

Figure 2. Location of sampling area at Ajibarang sub-district $\left(7^{\circ} 25^{\prime} 28.380^{\prime \prime} \mathrm{LS} 109^{\circ} 4^{\prime} 8.751^{\prime \prime} \mathrm{BT}\right)$, Sumbang sub-district $\left(7^{\circ} 21^{\prime} 50.795^{\prime \prime} \mathrm{LS} 109^{\circ} 16^{\prime} 16.531^{\prime \prime} \mathrm{BT}\right)$, Banyumas sub-district $\left(7^{\circ} 31^{\prime} 43.898^{\prime \prime} \mathrm{LS} 109^{\circ} 16^{\prime} 16.531^{\prime \prime} \mathrm{BT}\right)$ and Sumpiuh sub-district $\left(7^{\circ} 35^{\prime} 10.976^{\prime \prime} \mathrm{LS} 109^{\circ} 21^{\prime} 59.125^{\prime \prime} \mathrm{BT}\right)$ in Banyumas Regency $\left(7^{\circ} 36^{\prime} 42^{\prime \prime} \mathrm{S}, 109^{\circ} 21^{\prime} 13^{\prime \prime} \mathrm{E}\right)$

food for human or as a mixture of chicken feed [7]. Despite its importance, there are no intensive cultivation of eel in Indonesia.

The aim of this research was to understand the difference between (1) reproduction parameters (fecundity, gonadal maturity level (GML), and gonadal maturity index (GMI)); (2) histological features of female and male gonadal development (oogenesis and spermatogenesis); (3) range of body length in each sexual phase; and (4) range of body length in each GML stage of captured eel from Banyumas regency of Central Java.

\section{MATERIALS AND METHOD}

\section{Research materials}

The material used in this research were male and female eels with a body length of 10-29 $\mathrm{cm}$ for female and $>30 \mathrm{~cm}$ for male [8].

\section{Research method and study sites}

This research was using a stratified random sampling method to determine four sub-districts as repre- sentative of total 27 sub-districts in Banyumas Regency, Central Java, Indonesia. The selected sub-districts were Ajibarang, Sumbang, Sumpyuh, and Banyumas. We chose three villages from each sub-district as the location for capturing eel. These chosen villages were as follows: Tipar Kidul, Kalibenda, and Pancasan of sub-district Ajibarang; Karanggintung, Tambaksogra, and Banteran of sub-district Sumbang; Nusadadi, Karet, and Selanegara of sub-district Sumpyuh; and Pekunden, Kejawar, and Dawuhan of sub-district Banyumas (Figure 2).

The four sub-districts were representing four different conditions of land functions. Sumpyuh and Banyumas sub-districts represented natural rice field area. On the other hand, Sumbang and Ajibarang subdistricts represented a residential and industrial area with a change of function of rice field into plantation (orange, chili, maize and others).

\section{Morphometric identification of eel sex}

Referring to research by Riani and Ermawati [8] in 


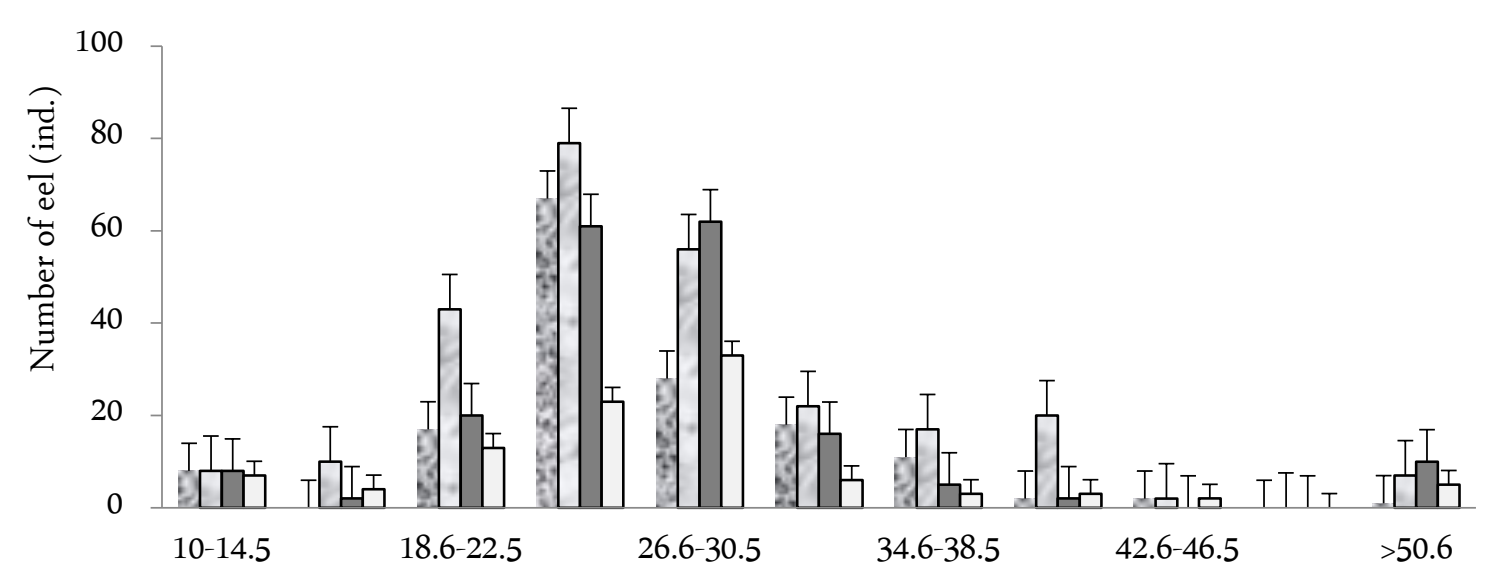

Body length interval of eel $(\mathrm{cm})$

a Ajibarang $\square$ Sumpyuh $\square$ Banyumas $\square$ Sumbang

Figure 3. Number of captured eels in each body length interval group

Central Java, Yogyakarta, and West Java, we can use body length of eel for sex differentiation. Eel with body length $<29 \mathrm{~cm}$ is a female, while eel with body length $>$ $30 \mathrm{~cm}$ is a male.

\section{Gonad Maturity Index (GMI)}

The GMI was calculated by comparing the weight of the gonads with the body weight of the fish and multiplied by one hundred percent by Effendie's formula [9]:

Note:

$$
G M I=\frac{G W}{B W} \times 100 \%
$$

GW: Gonad Weight

BW: Body Weight

\section{Gonad Maturity Level (GML)}

The GML was identified according to the description of GML by Taufik and Saparinto's Method [10].

\section{Identification of eel's gonad histology}

The preparation of gonad histology of male and female eel was using paraffin method with HaematoxylinEosin staining according to Suntoro Method [11], which has been modified by our Structure and Development Laboratory. The slide was observed using a light microscope with $400 \times$ of magnification.

\section{Ricefields superficial water quality}

The supporting data was water quality during the research. Physical analysis of water was including tem- perature and $\mathrm{pH}$. Water temperature was measured using mercury thermometer $\left({ }^{\circ} \mathrm{C}\right)$. The degree of acidity was measured using calibrated $\mathrm{pH}$ meter.

\section{Data analysis}

Monthly data of eel's GMI, Fecundity, and GML from 12 villages of four sub-districts in Banyumas Regency were presented in table and bar chart. The histological features of the gonads were analyzed descriptively.

\section{RESULTS AND DISCUSSION \\ Number of captured eels}

The total number of captured eels were 631; which were consisted of 155; 227; 157; and 92 eels from Ajibarang, Sumpyuh, Banyumas, and Sumbang, respectively (Figure 3). We divided the body length data of eels into eleven body length intervals. Majority of captured eels in 4 sub-districts were in the $22.6-26.5 \mathrm{~cm}$ of the body length interval group.

In May 2017, the majority of sub-district in Banyumas Regency had entered the rice planting season with adequate water on the surface of rice fields. The captured eels were still available, although the planting season had been begun in February 2017. However, in June and July 2017, there was no adequate water on the surface of rice field, and eels were more difficult to obtain.

In Sumpyuh, the beginning of the rice planting season was at the end of March or in early April. Therefore, in May, June, and even July 2017 eels were still easy to obtain. Eels from Sumpyuh sub-district dominated both 
in the number, body length, and body weight. In contrast, eels from Sumbang sub-district had the lowest number among four sub-districts. Furthermore, there were no eels with a body length between 30.6 and 34.5 $\mathrm{cm}$ in Sumbang. In Sumpyuh sub-district, there was female eel with $51 \mathrm{~cm}$ of body length, $121 \mathrm{~g}$ of weight, and $5.89 \mathrm{~g}$ of gonadal weight $(\mathrm{GMI}=0.48)$. There was also male eel with $71 \mathrm{~cm}$ of body length, $298 \mathrm{~g}$ of body weight, and $0.48 \mathrm{~g}$ of gonad weight. These findings were different from the data from Susatyo and Sugiharto [12], which stated that the female eel from the Banyumas region had $15-20 \mathrm{~g}$ of body weight and $20 \mathrm{~cm}$ of body length. Natural feature of rice fields in Sumpyuh subdistrict, which adequately provide the nutritional needs for eel's growth, might be the cause of these differences. Also, the soil of rice fields in Sumpyuh sub-district contained the highest clay contents among four sub-districts.

Clay contents of the soil represent the nutritional source for eel's growth $[13,14]$. Clay content in Sumpyuh, Ajibarang, Banyumas, and Sumbang sub-districts were $41.75 \%, 38.56 \%, 35.58 \%$, and $28.3 \%$, respectively (Primary data, results of the Agronomy Laboratory Analysis, Faculty of Agriculture Unsoed, 2017).

Furthermore, in Banyumas and Sumpyuh sub-districts, there were many rice milling factories, which activities cause high noise and vibration. However, these factories were located quite far from rice field area, where eels were captured. Therefore, the life of eels in the rice fields was not significantly disturbed.

\section{Gonad maturity level and sex change}

The GML of captured eels in this research can be seen in Figure 4A, 4B, 4C, and 4D. This result was different from research by Riani and Ernawati [8], which stated that eels with body length of 16.9-20.8 cm have GML-II and GML-III. There were eels with a body length of $16.9-20.8 \mathrm{~cm}$, which already underwent transition period or sex change. Eels with GML-IV were only found at a body length interval of $24.9-28.8 \mathrm{~cm}$. In addition, Ani and Ernawati [8] explained that female eels had body length of $<29 \mathrm{~cm}$ and changed into a male at a body length of $>29 \mathrm{~cm}$. Body length interval $32.9-$ $36.8 \mathrm{~cm}$ and $40.9-44.8 \mathrm{~cm}$ were only found in male eel. Therefore, in their research, eel with a body length of $32.9 \mathrm{~cm}$ had been started to change into a male.

Chadijah [15] explained that the female sex phase of eel was achieved at GML-III. At the GML-III stage, the weight of gonads reaches its maximum and the eggs were started to be released. The value of GIS in the transition phase (GML-V) were decreased because of the gonad weight in that phase was zero. The highest score of GSI of male eels was achieved on GML-VIII, because of the gonad weight in that phase reached its maximum.

Environmental factors such as substrate and alkalinity might be the cause of the differences in data between sub-districts in this research. These factors can accelerate the conversion of eel's sex into a male. In this state, eel is already old. Sex change occurs because the eel is a protogynous hermaphrodite with multiple genitals, which will be changed from female to male in its older age [16].

Eel life cycle begins with the differentiated juvenile period. Furthermore, it develops into females and subsequently undergoes an intersex or transitional period. After this period, the eel will turn into a functional adult male [17]. Also, reproduction status or sex of eel also can be determined by its body length.

Rice fields along Ajibarang and Wangon highway have now become an industrial area (e.g., Bima cement, recreation, sand mining, rock mining, and mineral water industry). This functional change of lands might cause habitat reduction of eel. The waste product might also contaminate its source of life. The impact can be seen in the delayed of achievement of the GML-IV stage. However, the result of $\mathrm{pH}$ measurement on Ajibarang rice fields was still within the normal range for growth of organism according to Dewi et al. [18], which was 6 7. The results of $\mathrm{pH}$ measurement on the Ajibarang rice field (around the location of the Bima cement industry) were within the range of $6.2-6.6$.

The temperature of the water surface of rice fields in 4 sub-districts was within the range of $26.2-27.6^{\circ} \mathrm{C}$. According to Kordi [19], the optimal temperature for eel's growth was within the temperature of $25-32^{\circ} \mathrm{C}$. A similar result also found by Fujiani [20], which stated that temperature of $20-27.8^{\circ} \mathrm{C}$ and $\mathrm{pH} 7$ is a proper medium for eel's growth.

District was achieved faster than eel from Ajibarang sub-district. It was achieved at $10-14.5 \mathrm{~cm}$ of body length interval. The GML-IV of eel from Sumpyuh sub-district was achieved at $26.5-30.5 \mathrm{~cm}$ of body length interval. It was also faster than the achievement of eel from Ajibarang sub-district.

Sumbang sub-district had the lowest number of captured eels. Furthermore, another factor that affects the number of captured eel in this sub-district was clay content. In their original habitat, eel consumes invertebrates 
and vertebrates including fish $[13,14]$. Eel also consumes Mollusca, frog, fish egg [21, 22]. 


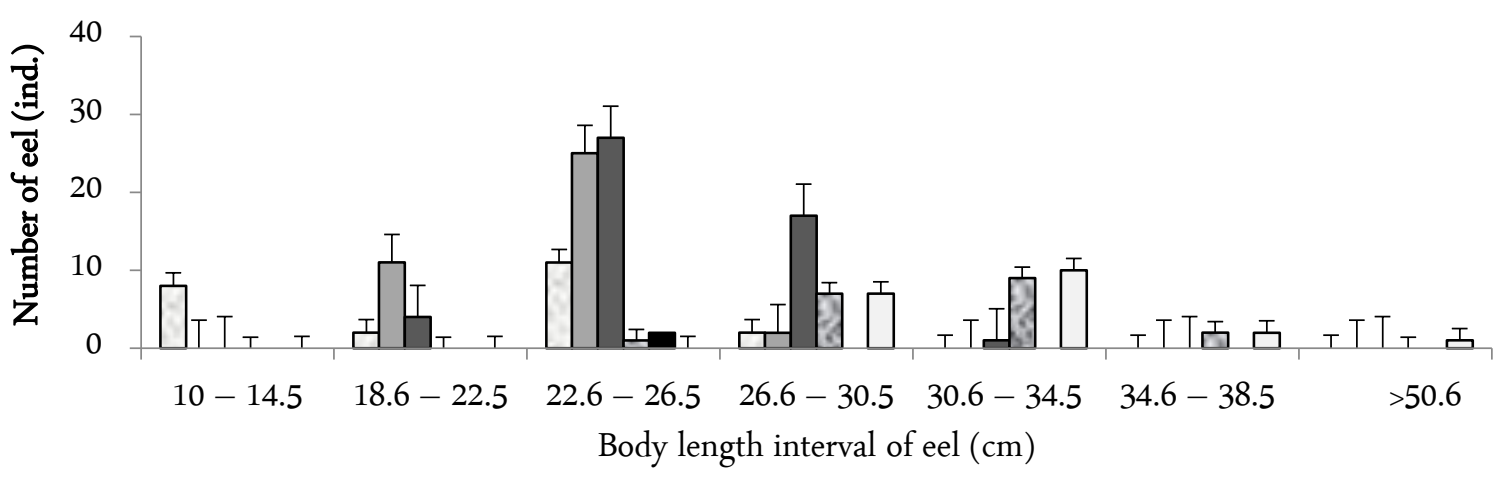

(a)

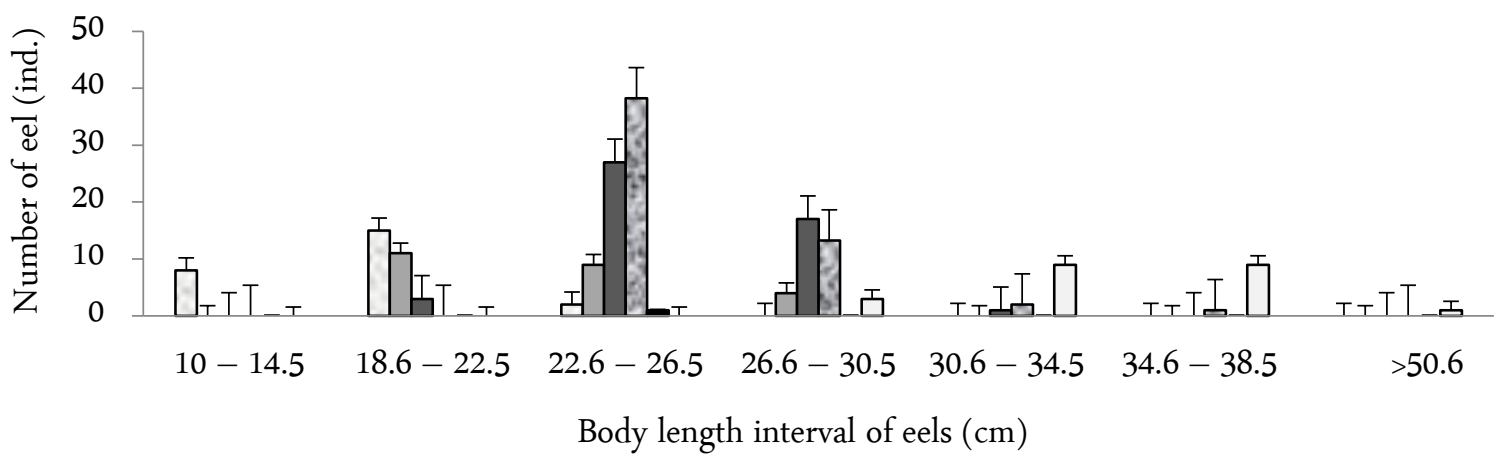

(b)

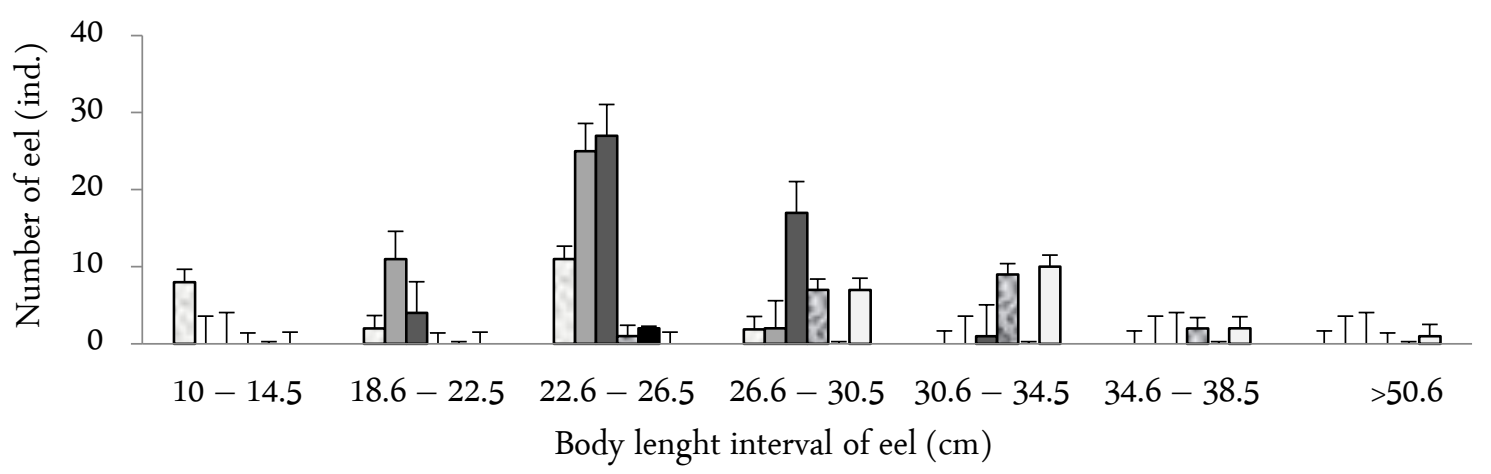

(c)

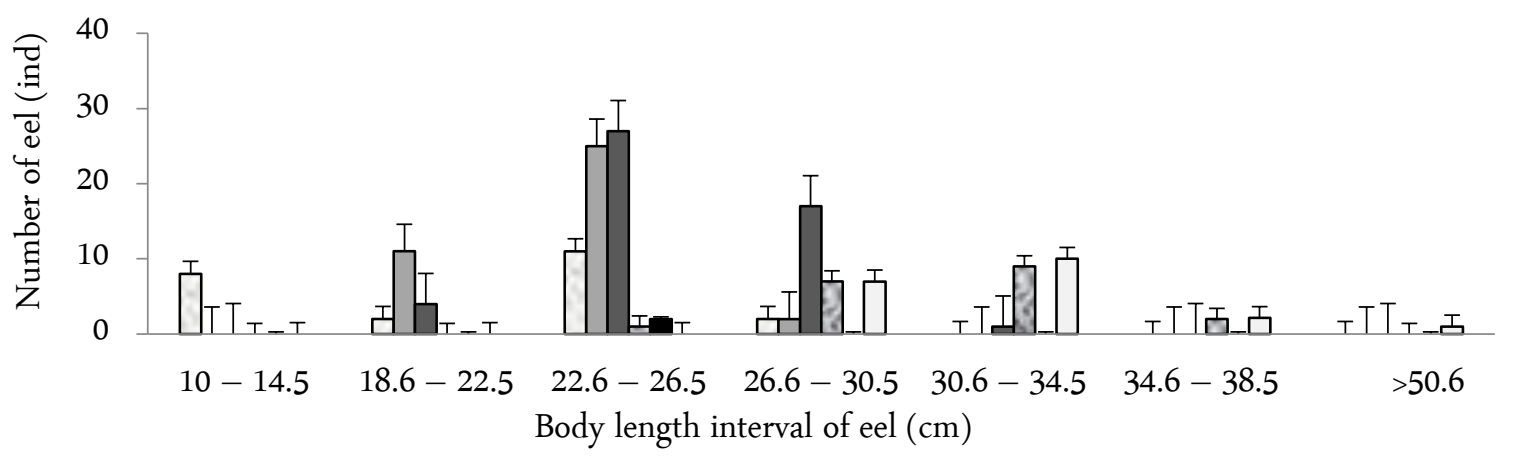

$\square^{\text {GML-1 }} \square^{\text {GML-2 }} \quad \square^{\text {GML-3 }} \quad \square^{\text {GML-4 }} \square^{\text {Intersex }} \square^{\text {Male }}$

(d)

Figure 3. The number of captured eels and Sex versus GML on Specific Body length intervals in A) Ajibarang; B) Sumpyuh; C) Banyumas: and D) Sumbang sub-district 
On the location of eel capturing in the three subdistricts (except Sumbang), eels were found in the mature form of sex (the female with GML-IV) at $16.9 \mathrm{~cm}$ of body length. These eels underwent sex change on varied body length. There was eel in intersex stage at 20.8 $\mathrm{cm}$ of body length. At body length interval of 27.4 $35.8 \mathrm{~cm}$, eel underwent sex changing into a male. These results are different with research by Riani and Ermawati [8], which stated that eel with $10-29 \mathrm{~cm}$ of body length has female sex, while eel with $>30 \mathrm{~cm}$ of body length has changed into male. Rice field eel species is a protogynous hermaphrodite, which starts its reproductive stadium and mature as a functional female. Subsequently, it will differentiate into intersex individual and grows larger until it becomes a functional male [22].

These data showed that sex change was not determined by eel's body length. It tends to be determined by eel's age. Eel body length in certain age can be varied. It depends on genetic, nutrient, and environmental factors [23].

Chadijah [15] observed the relationship between body weight and body length of eel at Sidenreng Lake in Sidenreng Rappang Regency, South Sulawesi. She stated that female eel had body length within the interval of $33.1-66.2 \mathrm{~cm}$, body length average of $42.4 \mathrm{~cm}$, body weight within $38.113-294.884 \mathrm{~g}$, and body weight average of $92.242 \mathrm{~g}$. The intersex eel had body length within $36.5-67.5 \mathrm{~cm}$, body length average of $45.3 \mathrm{~cm}$, body weight within $53.630-311.121 \mathrm{~g}$, and body weight average of $105.157 \mathrm{~g}$. Eel reached male sex stage when its body length within $44.5-70.0 \mathrm{~cm}$, body length average of $48.5 \mathrm{~cm}$, body weight within $100.110-343.889$ $\mathrm{g}$, and body weight average of $135.869 \mathrm{~g}$.

Sex change on eel happens because of its nature as the protogynous hermaphrodite, which undergoes sex change from female into a male. This change happens because, in the gonad of eel, there are both ovary and testes. During their lifetime, the eel will undergo several changes. In juvenile stage, it is undifferentiated. As the ovary developing, it becomes female. After becomes female, its ovary will eventually shrink and eel enter the intersex stage. Finally, the testes will be developed and eel becomes a functional male [24].

Figure $4 \mathrm{~A}, 4 \mathrm{~B}, 4 \mathrm{C}$, and $4 \mathrm{D}$ illustrate the influence of a functional change of the lands (as the habitat of eel) and activities (farming, constructing, and waste product disposing of an industry) from the four sub-districts. As a result, there was a low number of captured eels, a delayed maturity of the gonad, and extreme cases of a female with body length above $50 \mathrm{~cm}$ and male with body length above average.

\section{Gonad maturity index}

Gonad Maturity Index (GMI) is the value in percentage as the result of comparison between gonad weight and eel body weight. The number of eels captured and their relationship with GMI on each sub-district can be seen in Table. Furthermore, it is confirmed on GML data in each sub-district at Figure 4A, 4B, 4C, and $4 \mathrm{D}$.

In Ajibarang, gonad maturation happened in body length interval of $26.6-30.5 \mathrm{~cm}$. As the example, eel with a body length of $29.2 \mathrm{~cm}$ had GMI 0.6835. These data showed that in the interval of $26.6-30.5 \mathrm{~cm}$, eel was prepared to spawn with a large size of the gonad. In Sumpyuh sub-district, female eel with mature gonad had body length intervals of $22.6-26.5 \mathrm{~cm}$ and 26.6-30.5 $\mathrm{cm}$ with the highest GMI within 0.835 - 2.32. In Banyumas sub-district, female eel with mature gonad had body length intervals of $22.6-26.5 \mathrm{~cm}$ and 26.6$30.5 \mathrm{~cm}$ with the highest GMI of 0.425 . On the other hand, there was no mature gonad in eels from Sumbang sub-district. Eel in Sumbang sub-district had the highest GMI of 0.275 .

According to Figure 4, there was female eel with $5.89 \mathrm{~g}$ of gonad weight, $121 \mathrm{~g}$ of body weight, and $51 \mathrm{c}$ of body length from Nusadadi Village in Sumpyuh subdistrict. Therefore, its calculated GMI was 0.48. This female eel Gonad Maturity Index (GMI) or Gonad Somatic Index (GSI) was 0.48. After its fecundity being calculated, there were 363 eggs of this female with the diameter between $1.3 \mathrm{~mm}$ and $3 \mathrm{~mm}$. Although the GMI was not above 0.6 , this female was not ready to spawn. Whereas, the eel with the highest body weight (298 g) and the highest body length $(71 \mathrm{~cm})$ had $0.4 \mathrm{~g}$ of gonad weight and male sex. This large male eel was also captured at Nusadadi Village in Sumpyuh Sub-district.

Gonad Maturity Index was correlated with Gonad Maturity Level. The GMI was increasing in female sex phase and was decreasing on GML-IV. On GML-V, eel had entered the intersex phase. The GMI of male eel was increasing on GML VI-IX and was decreasing on GMLX. On research by Chadijah [15], a female phase was achieved in GML-III with maximum gonad weight. Therefore, indication for egg release was high. Value of GMI on GML-V was decreasing because of zero weight of the gonad. The highest GMI on male eel was achieved on GML-VIII because of maximum weight of the gonad at this stage. 
Table 1. Number of eels in four sub-district According to Gonad Maturity Index (GMI)

\begin{tabular}{ccccc}
\hline & \multicolumn{4}{c}{ Number of Eels (individuals) } \\
\cline { 2 - 5 } Interval of GMI & $\begin{array}{c}\text { Ajibarang Sub- } \\
\text { district }\end{array}$ & $\begin{array}{c}\text { Sumpyuh Sub- } \\
\text { district }\end{array}$ & $\begin{array}{c}\text { Banyumas Sub- } \\
\text { district }\end{array}$ & $\begin{array}{c}\text { Sumbang Sub- } \\
\text { district }\end{array}$ \\
\hline $0.0236-0.0445$ & 13 & 16 & 19 & 12 \\
$0.0446-0.0655$ & 4 & 13 & 16 & 11 \\
$0.0656-0.0965$ & 6 & 7 & 18 & 11 \\
$0.0966-0.3245$ & 18 & 43 & 26 & 18 \\
$0.3245-0.4275$ & 20 & 29 & 29 & 21 \\
$0.4275-0.5285$ & 11 & 26 & 13 & 6 \\
$0.5285-0.6865$ & 18 & 27 & 16 & 5 \\
$>0.6866$ & 20 & 57 & 11 & 0 \\
\hline
\end{tabular}
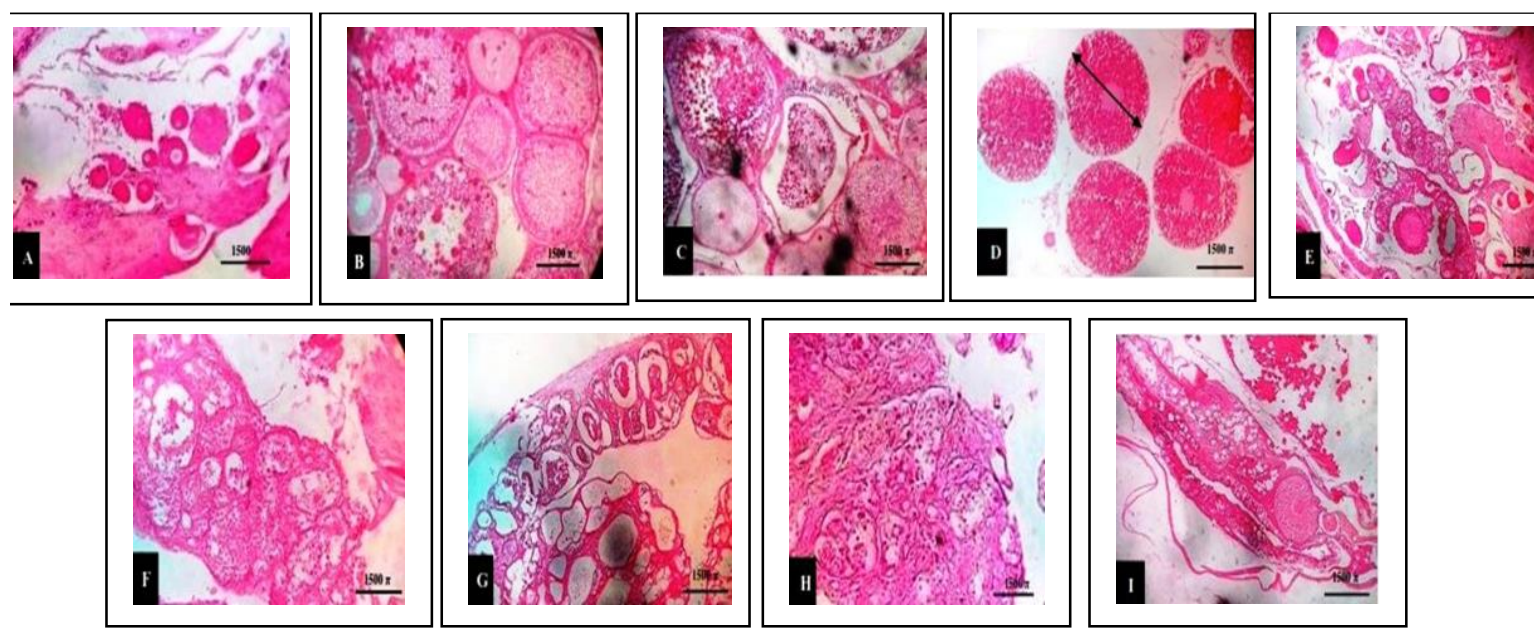

Figure 5. Micrograph / Histology of Gonad Development (Gonadogenesis) of Female, Intersex, and Male Eel. Note: (A) GML-I (10-14.5 cm and 14.6-18.5 cm of body length interval); (B) GML-II (18.6-22.5 cm of body length interval); (C) GML-III (22.6-26.5 cm of body length interval); (D) GML-IV (26.6-34.5 cm of body length interval); (E) intersex (26.5-34.5 cm of body length interval); (F) pre-functional male from intersex; (G) Functional Male (30.6-40 cm of body length interval);

(H) Lobulation of Testes; I. Atretic stage

\section{Development of gonad (gonadogenesis) in female, inter- sex, and functional male}

Sex change of rice field eel can be determined from its body length. It is confirmed by histological observation of eel's gonad. Morphologically, female eel had brownish-black back, yellowish-white abdomen, small head, and long sharp-end tail. The male eel had greenish-brown back, brownies yellow abdomen, large head, and short blunt-end tail. Microscopic figure of eel's gonad development showed that gonadogenesis or oogenesis in female eel was observed in the stages of GML-

Microscopic figure of eel's gonad development 1 (chromatin nucleolar stages and perinucleolar stage); GML-II (cortical alveolar formation stage or globular yolk stage), GML-3 (late globular yolk stage), GML-IV (mature or ripe stage), and follicle atretic stage. This result was similar to identification by Ravaglia and
Maggese [25]. Gonadogenesis or spermatogenesis in male eel is the reproduction process, which involved sexual differentiation process, regulation of germinal cell, and development of gonad somatic cell [26]. This process was observed in pre-functional and functional male stage.

\section{Fecundity and diameter of female eggs}

Fecundity measurement is important to understand the dynamic of the population and life history of fish [17]. Fecundity is the amount of eggs, which were released from the ovary before spawning. It affects the number of produced tillers. Fecundity is strongly related to body weight, body length, age, diameter of egg, and the egg protection manner. Fish with high fecundity had no egg protection habit. It also had small eggs. Current 
Table 2. The diameter of egg of captured eel in the four sub-districts

\begin{tabular}{ccccccccc}
\hline Interval of Egg Di- & \multicolumn{2}{c}{ Ajibarang Sub-district } & \multicolumn{2}{c}{ Sumpyuh Sub-district } & \multicolumn{2}{c}{ Banyumas Sub-district } & \multicolumn{2}{c}{ Sumbang Sub-district } \\
\cline { 2 - 9 } ameter & GML-III & GML-IV & GML-III & GML-IV & GML-III & GML-IV & GML-III & $G M L-I V$ \\
\hline $0.0625-0.1624$ & 193 & 11 & 152 & 22 & 121 & 0 & 83 & 0 \\
$0.1625-0.2624$ & 90 & 33 & 76 & 30 & 68 & 0 & 76 & 0 \\
$0.2625-0.3624$ & 11 & 11 & 2 & 0 & 4 & 0 & 2 & 0 \\
$0.3625-0.4624$ & 19 & 21 & 33 & 21 & 5 & 0 & 5 & 0 \\
$0.4625-0.5624$ & 5 & 25 & 11 & 22 & 2 & 0 & 2 & 0 \\
$0.5625-0.6624$ & 3 & 6 & 0 & 11 & 0 & 0 & 0 & 0 \\
$0.6625-0.7624$ & 2 & 4 & 0 & 13 & 0 & 0 & 0 & 0 \\
$0.7625-0.8624$ & 0 & 2 & 0 & 0 & 0 & 0 & 0 & 0 \\
$0.8625-0.9624$ & 0 & 1 & 0 & 12 & 0 & 0 & 0 & 0 \\
$0.9625-1.0624$ & 0 & 6 & 0 & 17 & 0 & 0 & 0 & 0 \\
$1.0625-1.1624$ & 0 & 15 & 0 & 3 & 0 & 0 & 0 & 0 \\
$1.1625-1.2624$ & 0 & 13 & 0 & 0 & 0 & 0 & 0 & 0 \\
$1.26225-146554$ & 0 & 0 & 8 & 1 & 0 & 0 & 0 & 0 \\
$1.46555-1.7654$ & 0 & 0 & 7 & 3 & 0 & 0 & 0 & 0 \\
$1.7655-2.2555$ & 11 & 0 & 6 & 9 & 0 & 0 & 0 & 0 \\
$2.2556-3.1455$ & 19 & 20 & 59 & 32 & 0 & 0 & 0 & 0 \\
Total of Eggs & 353 & 168 & 363 & 194 & 200 & 0 & 168 & 0 \\
\hline
\end{tabular}

research showed that fecundity of eel was within the range of $36-363$ eggs and had 95 eggs on average. This low fecundity might be caused by its habit of protecting eggs. It is similar to the result of a research by Bozkurt and Öğretmen [27], which showed that fish with eggs protecting habit had low fecundity.

According to Damsgaard [28], fertilized egg of rice field eel will be swallowed into male's mouth. Furthermore, the male eel will spread it out in its new hiding hole in the soil. The eggs will be left by the male eel after 15 days post-hatching. The diameter of eel's egg in current research is presented in Table 2.

Table 2 showed that in the certain stadium, there were several diameters of eggs. This finding showed that development of egg cells in eel's gonad was relatively not similar. Therefore, these eggs cannot be released at the same time, which was resulting in the different size of eggs. In Sumbang sub-district, there was no eel with GML-IV. Even in gonad that was ready to spawn, GMLIV eel showed the multilevel peak of eggs diameter. Type of eel spawning can be determined either by its eggs diameter or its histological features [29]. Based on these parameters, a fish can be divided into total spawner or partial spawner type. In total spawner type fish, diameter and histological figure of eggs in its gonad are relatively similar. On the other hand, in partial spawner type fish, there are different size of egg's diameter. In the current research, the eggs had more than one peak in diameter and the different size on histological examination. Therefore, eel is a partial spawner type [30].
In a total spawner fish, diameter and histological figure of eggs in its gonad are relatively similar. In contrast, partial spawner fish had different size of eggs [31]. Generally, among all of the parameters in this research, environmental factors, availability natural feed, and nutrition effect on life sustainability, growth, sex maturation, and another period [32].

Laboratory examination result of clay contents of soil in Sumpyuh, Ajibarang, Banyumas, and Sumbang sub-districts were $41.75 \%, 38.56 \%, 35.58 \%$, and $28.3 \%$, respectively (Primary data of Agronomy Laboratory Analysis of Faculty of Agriculture, Unsoed, 2017). Clay content of eel habitat facilitates the availability of eel's natural feed. In Sumpyuh sub-district, as the best location, the soil was contained earthworms and snails. Earthworms are one of the feeds that contains proteins. It contains $67-76 \%$ of protein [33].

Generally, among all of the parameters in this research, environmental factors, availability natural feed, and nutrition have an effect for life sustainability, growth, sex maturation, and another period.

\section{CONCLUSION}

Based on the discussion section below, can be concluded that:

1. Sex change of eel from female to male occurred at $29 \mathrm{~cm}$ of body length. Sex change was determined by eel's age. Eel is a fish, which had eggs protecting habit. It was resulting in low fecundity, which was within the range of 36-363 eggs. Eel is a partial 
spawner fish. The highest number of captured eel was within the body length interval of $22.6-26.5$ $\mathrm{cm}$. Stage of GML-IV was achieved in eel's body length range of 22.6-34.5 cm in Sumpyuh, 22.6-38.5 $\mathrm{cm}$ in Ajibarang, and 26.6-34.5 cm in Banyumas. There was no eel that reached the status of GMLIV in Sumbang. The GMI was within the range of $0.023-0.686$.

2. Oogenesis was observed in the stages of GML-1 (chromatin nucleolar stages and perinucleolar stage); GML-II (cortical alveolar formation stage or globular yolk stage), GML-3 (late globular yolk stage), GML-IV (mature or ripe stage), and follicle atretic stage. Male gonadogenesis and spermatogenesis were observed in the intersex.

3. Eel in GML-I, GML-2, GML-3, and GML-IV had GMI within the range of 0.023-0.096, 0.096-0.425, $0.427-0.686$, and $>0.686$, respectively. The number of captured eel with GML-IV was obtained in Sumpyuh, Ajibarang, Banyumas, and Sumbang subdistricts were $57,20,11$, and 0 , respectively.

\section{ACKNOWLEDGMENT}

We would like to thank the Rector and the Chairman of LPPM of Jenderal Soedirman University (Unsoed) for the permission they gave for us to conduct this research on Unggulan Perguruan Tinggi-BLU Unsoed 2017 scheme.

\section{REFERENCES}

1. Hidayat HA, Hanafie U, Septiana N (2012) Dampak konversi lahan pertanian bagi taraf hidup petani di Kelurahan Landasan Ulin Barat Kecamatan Liang Anggang Kota Banjarbaru. Jurnal Agribisnis Perdesaan 2 (2): 1 - 13.

2. Affandi R, Ernawati Y, Wahyudi S (2003) Studi bio-ekologi belut sawah (Monopterus albus) pada berbagai ketinggian tempat di Kabupaten Subang, Jawa Barat. Jurnal Iktiologi Indonesia 3 (2): $1-7$.

3. Schofield PJ, Nico LG (2009) Salinity tolerance of non-native Asian swamp eels (Teleostei: Synbranchidae) in Florida, USA: Comparison of three populations and implications for dispersal. Journal Environmental Biology of Fishes 85 (1): 51 - 59. doi: 10.1007/s10641-009-9456-9.

4. Hill JE, Watson CA (2007) Diet of the nonindigenous Asian swamp eel in tropical ornamental aquaculture ponds in West- Central Florida. North American Journal of Aquaculture 69: $139-146$

5. Long JM, LaFleur C (2011) Estimation of daily age and timing of hatching of exotic Asian swamp eels Monopterus albus (Zuiew) in a backwater marsh of the Chattahoochee
River, Georgia, USA. Journal of Applied Ichthyology 27: 1019 - 1022. doi: 10.1111/j.1439-0426.2011. 01739.x.

6. Yin S, Liu Y (2010) Compositions and functions of the hatching froth from ricefield eel (Monopterus albus). Journal of Fish Physiology and Biochemistry 36: 195 - 200. doi: 10.1007/s10695-008-9274-6.

7. Pinkihan RW (2013) Nutrient composition and digestibility of Asian swamp eel (Monopteus albus) meal in broiler nutrition. International Journal of Science and Research 6 (14): 1 - 7. doi: 10.21275/v5i7.ART2016114.

8. Riani E, Ernawati Y (2004) Hubungan perubahan jenis kelamin dan ukuran tubuh ikan belut sawah (Monopterus albus). Jurnal Ilmu-ilmu Perairan dan Perikanan Indonesia 11 (2): $139-144$.

9. Effendie MI (2002) Biologi perikanan. Bogor, Yayasan Pustaka Nusantara.

10. Taufik A, Saparinto C (2008) Usaha pembesaran belut di kolam tembok, terpal, dan drum/tong. Jakarta, PT. Penebar Swadaya.

11. Suntoro SH (1983) Metode pewarnaan. Jakarta, Penerbit Bhratara Aksara.

12. Susatyo P, Sugiharto (2001) Aspek perubahan hormonal dan histologis selama perkembangan ovarium belut sawah (Monopterus albus Zuiew) yang diinduksi secara artifisial. Biosfera Scientific Journal 16 (3): 13 - 19. doi: 10.20884/1.mib.2012.29.3.247.

13. Cheng H, Guo Y, Yu Q, Zhou R (2003) The rice field eel (Monopterus albus) as a model system for vertebrate sexual development. Cytogenetic and Genome Research 101: $274-$ 277. doi: 10.1186/1297-9686-34-1-129.

14. Hill JE, Watson CA (2007) Diet of the nonindigenous Asian swamp eel in tropical ornamental aquaculture ponds in West-Central Florida. North American Journal of Aquaculture 69 (2): 139 - 146. doi: 10.1577/A05-070.1.

15. Chadijah A (2014) studi pendahuluan biologi reproduksi ikan belut (Monopterus albus Zuiew, 1793) di Danau Sidenreng Kabupaten Sidenreng Rappang. Journal Octopus 3 (1): $1-8$.

16. Avise JC, Mank JE (2009) Evolutionary perspective on hermaphroditism in fishes. Journal of Sexual Development 3: 152 - 163. doi: 10.1159/000223079.

17. Khanh NH, Ngan HTB (2010) Current practices of rice field eel (Monopterus albus Zuieuw, 1793). Aquaculture Asia Magazine 15 (3): 26 - 29.

18. Dewi NK, Prabowo R, Trimartuti NK (2014) Analisis kualitas fisiko kimia dan kadar logam berat pada ikan mas ( $C_{y}$ prinus carpio L.) dan ikan nila (Oreochromis niloticus L.) di Perairan Kaligarang Semarang. Biosaintifika: Journal of Biology and Biology Education 6 (2): 109 - 116. doi: 10.15294/biosaintifika.v6i2.3106. 
19. Kordi KMGH (2010) Panduan lengkap memelihara ikan air tawar di kolam terpal. Yogyakarta, Lily Publisher.

20. Fujiani T, Efrizal, Rahayu R (2015) Laju pertumbuhan belut sawah (Monopterus albus Zuiew) dengan pemberian berbagai pakan. Jurnal Biologi Universitas Andalas 4 (1): 50 $-56$.

21. Falahudin I, Mareta DE, Puspa RY (2016) Pengaruh pemberian keong sawah dan air cucian beras terhadap pertumbuhan belut (Monopterus albus Zuieuw). Biota 2 (1): 112 119.

22. Shafland PL, Gestring KB, Sanford MS (2010) An assessment of the Asian swamp eel (Monopterus albus) in Florida. Reviews in Fisheries Science 18 (1): 25 - 39. doi: 10.1080/10641260903225542.

23. Miah MF, Ali H, Zannath E et al. (2015) Breeding biology and induced breeding status of freshwater mud eel, Monopterus cuchia. International Journal of Bioengineering and Life Sciences 9 (6): $193-201$.

24. Todd EV, Liu H, Muncaster S, Gemmell NJ (2016) Bending genders: The biology of natural sex change in fish. Journal of Sex Development $10(5-6): 223$ - 241. doi: 10.1159/000449297.

25. Ravaglia MA, Maggese MC (2002) Oogenesis in the swamp eel Synbranchus marmoratus (Bloch, 1795) (Teleostei; synbranchidae). Ovarian anatomy, stages of oocyte development and micropyle structure. Biocell 26 (3): 325 - 237.

26. Gao Y, Jia D, Hu Q, Li D (2016) Foxl3, a Target of miR-9, stimulates spermatogenesis in spermatogonia during natural sex change in Monopterus albus. Journal Endocrinology. 157 (11): 4388 - 4399. doi: 10.1210/en.2016-1256.

27. Bozkurt Y, Öğretmen F (2012) Sperm quality, egg size, fecundity and their relationships with fertilization rate of grass carp (Ctenopharyngodon idella). Iranian Journal of Fisheries Science 11 (4): 755 - 764.

28. Damsgaard C, Findorf I, Helbo S et al. (2014) High blood oxygen affinity in the air-breathing swamp eel (Monopterus albus). Comparative Biochemistry and Physiology Part A: Molecular and Integrative Physiology 1 (78): 102 - 108. doi: 10.1016/j.cbpa.2014.08.001.

29. Nico LG, Sharp P, Collins TM (2011) Imported Asian swamp eels (Synbranchidae: Monopterus) in North American live food markets: Potential vectors of non-native parasites. Journal Aquatic Invasions 6 (1): 69 - 76. doi: 10.3391/ai.2011.1.08.

30. Dou SZ, Yamada Y, Okamura A et al. (2008) Temperature influence on the spawning performance of artificially-matured Japanese eel, Anguilla japonica, in captivity. Journal Environmental Biology of Fishes 8 (2): 151 - 164. doi: 0.1007/s10641-007-9268-8.

31. Kuhn KL, Near T, Near J, Detrich HW, Eastman, JT (2011) Biology of the Antarctic dragonfish Vomerdens infuscipinnis (Notothenioidei: Bathydraconidae). Antarctic Science 23 (1): $18-26$.

32. Mathialagan R. Sivakumar R (2017) Maturation and reproductive biology of reba carp Cirrhinus reba (Hamilton) in Lower Anicut Reservoir, Tamil Nadu, India. Fisheries and Aquaculture Journal 8 (3): 223 - 233. doi: 10.4172/21503508.1000223.

33. Mashuri, Sumarjan, Abidin Z (2012) Pengaruh jenis pakan yang berbeda terhadap pertumbuhan belut sawah (Monopterus albus Zuieuw). Jurnal Perikanan Unram. 1 (1): 1 7. 